\title{
Efficient Route to (2R)-6-Hydroxy-2-methyl- dihydropyridin-3-ones, Key Intermediates for Piperidine Alkaloids Syntheses
}

\author{
Evangelia N. Tzanetou ${ }^{1}$, Konstantinos M. Kasiotis ${ }^{2}$, Serkos A. Haroutounian ${ }^{1, *}$ \\ ${ }^{1}$ Chemistry Laboratory, Agricultural University of Athens, Iera Odos 75, Athens, 11855, Greece \\ ${ }^{2}$ Benaki Phytopathological Institute, Laboratory of Pesticides Toxicology, 8 St. Delta Street, Athens, Kifissia, 14561, Greece
}

\begin{abstract}
The efficient synthesis of (2R,6S)-6-hydroxy-2-methyl-1-tosyl-1,2-dihydropyridin-3(6H)-one 5 in five steps and $30 \%$ overall yield is reported. This dihydropyridone constitutes versatile chiral building block repetitively used in the synthesis of various piperidine alkaloids and may serve as key template for the construction of synthetic libraries of bioactive derivatives and analogues of the piperidine alkaloids.
\end{abstract}

Keywords Pyridones, Piperidine Alkaloids, Azasugars, Glucal

\section{Introduction}

Multifunctionalized piperidine alkaloids (including azasugars) constitute a distinct class of natural compounds widely found in living systems[1] that exhibit a wide range of biological activities, as a result of their ability to mimic carbohydrate substrates in a plethora of enzymatic processes [2,3]. These activities include glycosidase inhibition[4], tumour growth inhibition[5] and anti-HIV behaviour[6], making those particularly attractive synthetic targets.

Thus, an intense research effort has been devoted for the development of methodologies and synthetic strategies for the efficient approach of these compounds and their derivatives[7-10]. Among the various synthetic routes developed for their efficient access, the use of dihydropyridones as advanced intermediates -prior to their conversion to piperidines - constitutes a well reviewed important synthetic strategy $[11,12]$ that has been a long term objective of our research group [12 and references therein]. In this respect, a series of synthetic methods including the microwave- assisted synthesis, regioselective nucleophilic addition to pyridinium salts, incorporation of boronate esters to dihydropyridones, have been reported during the last 5 years as concise routes for the preparation of dihydropyridone derivatives[13-15].

Herein we report the efficient transformation of the commercially available 3,4-di-O-acetyl-6-deoxy-L-glucal 1 to $(2 \mathrm{R}, 6 \mathrm{~S})$-2-methyl-dihydropyridone 5 , which accounts as

\footnotetext{
* Corresponding author:

sehar@aua.gr (Serkos A. Haroutounian)

Published online at http://journal.sapub.org/ajoc

Copyright (C) 2012 Scientific \& Academic Publishing. All Rights Reserved
}

the key intermediate for the synthesis of many bioactive natural piperidine alkaloids, such as the molecules of $(-)$-Cassine, $(-)$-Spectaline, $(-)$-Carnavaline, Prosafrine and (-)-Prosafrinine. The literature reports implicating the derivatives of L-glucal in synthetic endeavours are limited and mainly refer to their transformation to L-ristosamine and L-epi-daunosamine glycosides[16].

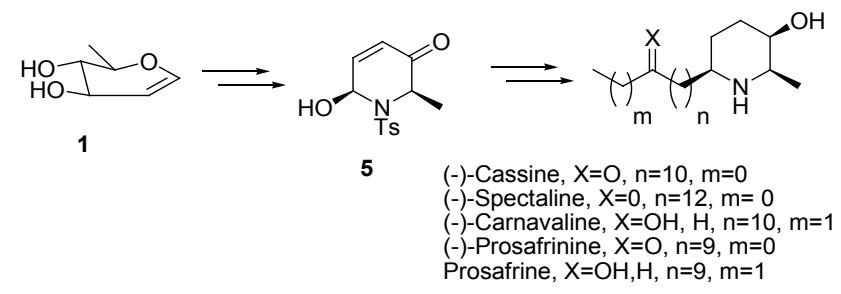

Figure 1. Piperidine alkaloids approached through the synthesis of key intermediate dihydropyridone 5

\section{Chemistry}

Our synthetic route substrate is the commercially available molecule of 3,4-di-O-acetyl-6-deoxy-L-glucal, which in acidic environment $\left(0.002 \mathrm{M} \mathrm{H}_{2} \mathrm{SO}_{4}\right.$ solution $)$ by reaction with $\mathrm{HgSO}_{4}$ was efficiently converted to the optically active furfural 2 , in accordance to a previously reported method [17]. The displacement of the secondary hydroxy group with the azide moiety, with the simultaneous inversion of its configuration, was performed in high enantiomeric excess ( $>98 \%$ ) by treating the compound 2 with DBU in toluene and DPPA. The enantiomeric excess of azide 3 was determined after the hydrogenation of the molecule for $50 \mathrm{~min}$ over $10 \%$ $\mathrm{Pd} / \mathrm{C}$ catalyst and 1 bar pressure[18]. The mixture was filtered over Celite ${ }^{\circledR}$ and the resulting amine was in situ derivatized with (-)-menthyl chloroformate, in the presence of 
$\mathrm{Et}_{3} \mathrm{~N}$. The enantiomeric ratio was determined by reversedphase HPLC [Kromasil 100-5, C-18, $\mathrm{H}_{2} \mathrm{O} / \mathrm{MeOH} / \mathrm{CH}_{3} \mathrm{CN}$ gradient elution from $45: 35: 20$ to $0: 20: 80$, flow $=1.1$ $\mathrm{mL} / \mathrm{min}$, UV detection at $238 \mathrm{~nm}$ ]; $\mathrm{t}_{\mathrm{R}}$ major $49.2 \mathrm{~min}(97 \%)$; and $t_{\mathrm{R}}$ minor $50.1 \min (3 \%)$.
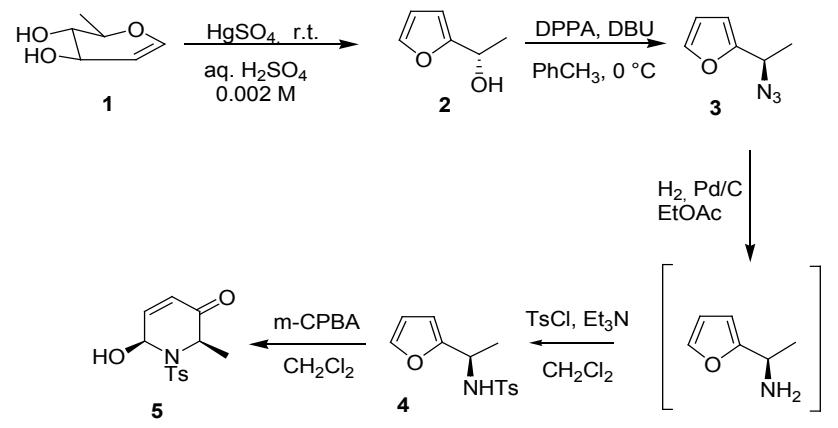

Scheme 1. Reagents and Conditions (a) DPPA, DBU, toluene, $0{ }^{\circ} \mathrm{C}$; (b) $\mathrm{H}_{2}$, $\mathrm{Pd} / \mathrm{C}, \mathrm{EtOAc}$; (c) TsCl, $\mathrm{Et}_{3} \mathrm{~N}, \mathrm{CH}_{2} \mathrm{Cl}_{2}$; (d) m-CPBA, $\mathrm{CH}_{2} \mathrm{Cl}_{2}$

On the other hand, the hydrogenation of 3 over $\mathrm{Pd} / \mathrm{C}$ and subsequent in situ tosylation of the resulting amine afforded the (R)-N-furfurylsulfonamide 4. Finally, the oxidative cyclization of compound 4 , using a modified version of the standard aza-Achmatowich rearrangement conditions, provided the target dihydropyridone 5 .

The diastereomeric purity of the product was revealed by ${ }^{1} \mathrm{H}-\mathrm{NMR}$ and HPLC, since the presence of the other diastereoisomer was not detected, while the stereochemistry of the newly formed stereocenter was determined by 2DNOESY spectroscopic analysis (the absolute configuration of $\mathrm{C}-2$ derived from the starting material). Thus, the clear strong cross peak observed between the protons on C-2 and C-6 confirms their cis pseudo-diaxial conformation (Figure 2).

Finally, the observed value of optical rotation of this compound $\left([\alpha]_{\mathbf{D}}^{22}=-24.4\right)$ constitutes an additional proof of the assigned configuration, since its enantiomer displays the opposite sign $\left([\alpha]_{\mathbf{D}}^{22}=+24.9\right)$.
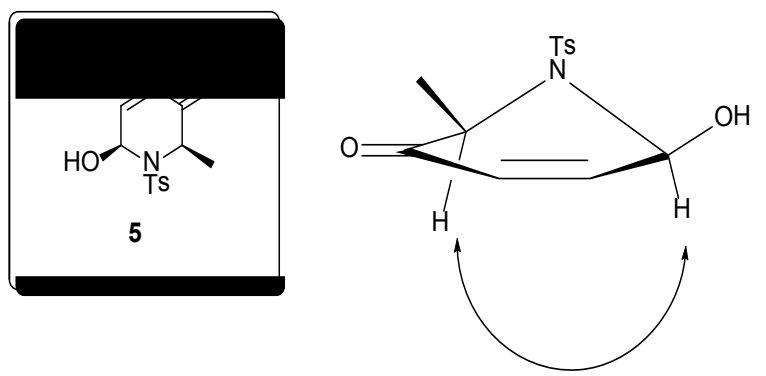

Figure 2. NOE correlation in dihydropyridone 5

\section{Experimental Part}

Air- and /or moisture sensitive reactions were carried out under argon atmosphere in flame-dried glassware. Solvents were distilled from the appropriate drying agents prior to use. All starting materials were purchased from Aldrich (analytical reagent grades) and used without further purification.

All reactions were monitored by thin-layer chromatogra- phy using TLC sheets coated with silica gel 60 F254 (Merck); spots were visualized with UV light or by treatment with. Products were purified by flash chromatography on Merck silica gel 60 (230-400 mesh ASTM). Melting points (uncorrected): Büchi melting point apparatus. FT-IR: Nicolet Magna 750, series II. Samples were recorded as $\mathrm{KBr}$ pellets, unless otherwise stated. ${ }^{1} \mathrm{H}$ NMR spectra were recorded on a Bruker DRX-400 (400 MHz) spectrometer, in the indicated solvents. Chemical shifts are referenced to internal TMS.

HPLC measurements were performed using an Agilent 1100 series instrument equipped with a variable UV wavelength detector and coupled to HP ChemStation utilizing the manufacturer's 5.01 software package.

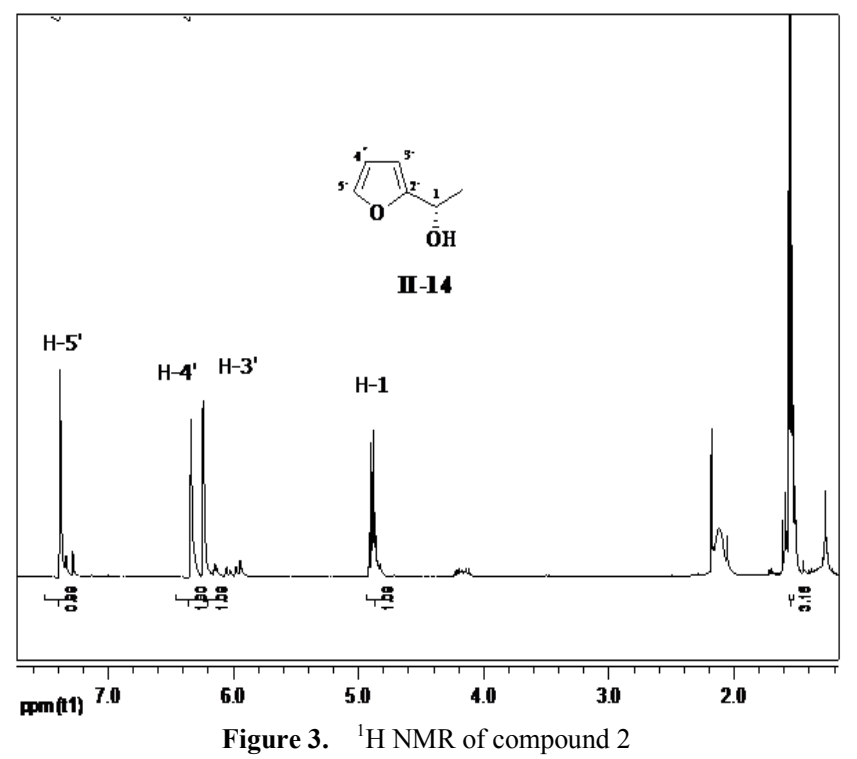

(S)-1-(furan-2-yl)ethanol，2: $0.37 \mathrm{~g}(2.84 \mathrm{mmol})$ Of 3,4-di-O-acetyl-6-deoxy-L-glucal 1 were stirred at room temperature in an aqueous solution of $\mathrm{H}_{2} \mathrm{SO}_{4}(0.002 \mathrm{M})$ in the presence of $0.017 \mathrm{~g}(0.057 \mathrm{mmol})$ of $\mathrm{HgSO}_{4}$. The reaction was completed after $3 \mathrm{~h}$ of stirring (revealed by TLC). Then the reaction mixture was extracted with EtOAc $(3 \times 20$ $\mathrm{mL}$ ) and the combined organic layers were extracted with 30 $\mathrm{mL}$ of a saturated solution of $\mathrm{NH}_{4} \mathrm{Cl}$. The organic phase was separated, dried over $\mathrm{MgSO}_{4}$ and concentrated under reduced pressure to give $0.33 \mathrm{~g}$ of compound 2 as a colourless oil ( $76 \%$ yield), which was further used without any additional purification.

${ }^{1} \mathrm{H}$ NMR $(400 \mathrm{MHz}) \mathrm{CDCl}_{3} \delta_{H}: 1.56(\mathrm{~d}, \mathrm{~J}=6.5 \mathrm{~Hz}, 3 \mathrm{H}$, $\left.\mathrm{C}^{-} \mathrm{CH}_{3}\right), 4.88(\mathrm{q}, \mathrm{J}=13.1,6.5 \mathrm{~Hz}, 1 \mathrm{H}, \mathrm{H}-1), 6.25(\mathrm{~d}, \mathrm{~J}=3.1$ Hz, 1H, H-3'), 6.35 (m, 1H, H-4'), 7.35 (s, 1H, H- 5').

(R)-2-(1-azidoethyl)furan, 3: To an ice-cold stirred solution of $50 \mathrm{mg}(0.38 \mathrm{mmol})$ of furanylethanol and $0.1 \mathrm{~mL}$ $(0.47 \mathrm{mmol})$ DPPA in $1 \mathrm{~mL}$ of anhydrous toluene $0.068 \mathrm{~mL}$ $(0.47 \mathrm{mmol}) \mathrm{DBU}$ were added dropwise. The resulting biphasic system was stirred at this temperature for $2 \mathrm{~h}$ and at room temperature for additional 20 hours. After revealing the end of the reaction (TLC), the reaction mixture was washed successively with $\mathrm{H}_{2} \mathrm{O}(2 \times 1 \mathrm{~mL})$ and aqueous $\mathrm{HCl}$ $(5 \%, 1 \mathrm{~mL})$. The organic layer was dried with $\mathrm{MgSO}_{4}$ and concentrated under reduced pressure. The oily residue was 
flash chromatographed using hexane/EtOAc 95:5 as eluent to provide $38 \mathrm{mg}$ of furan 3 as a colourless oil ( $70 \%$ yield).

${ }^{1} \mathrm{H}$ NMR $(400 \mathrm{MHz}) \mathrm{CDCl}_{3} \delta_{H}: 1.5(\mathrm{~d}, \mathrm{~J}=6.5 \mathrm{~Hz}, 3 \mathrm{H}$, C-CH $\left.{ }_{3}\right), 4.5(\mathrm{~m}, 1 \mathrm{H}, \mathrm{H}-1), 6.2\left(\mathrm{~d}, \mathrm{~J}=3.2 \mathrm{~Hz}, 1 \mathrm{H}, \mathrm{H}-3^{\prime}\right), 6.3$ (m, 1H, H-4'), 7.4 (d, J = 1.7 Hz, 1H, H-5').

(R)-N-(1-(furan-2-yl)ethyl)-4-methylbenzenesulfonami de, 4: $60 \mathrm{mg}(0.44 \mathrm{mmol})$ of (R)-2-(1-azidoethyl)furan 3 in $10 \mathrm{~mL}$ EtOAc were hydrogenated at atmospheric pressure using as catalyst $10 \% \mathrm{w} / \mathrm{w} \mathrm{Pd} / \mathrm{C}(0.04 \mathrm{~g})$. After $1.5 \mathrm{~h}$ of stirring the reaction was completed and the solution was filtered through celite. The filtrate was dried over $\mathrm{MgSO}_{4}$ and concentrated under reduced pressure to provide an oily residue. Then, $3 \mathrm{~mL} \mathrm{CH}_{2} \mathrm{Cl}_{2}$ and $0.12 \mathrm{~mL} \mathrm{Et}_{3} \mathrm{~N}(0.9 \mathrm{mmol})$ were added, cooled to $0{ }^{\circ} \mathrm{C}$ and $0.07 \mathrm{~g}(0.49 \mathrm{mmol})$ of benzoyl-chloride were added gradually under stirring. After completion of the addition, the reaction temperature was maintained at $0^{\circ} \mathrm{C}$ for $10 \mathrm{~min}$ and then allowed to proceed the room temperature and stirred for additional $3 \mathrm{~h}$. Then, the reaction mixture was quenched with saturated solution of $\mathrm{NaHCO}_{3}$ and brine was added. The organic phase was separated, dried over $\mathrm{MgSO}_{4}$ and concentrated under reduced pressure. The resulting yellow solid was flash chromatographed using as eluent hexane/EtOAc 8.5:1.5, providing $77 \mathrm{mg}$ of sulphonamide 4 (yield, 67\%), which recrystallizes as white crystals from $\mathrm{Et}_{2} \mathrm{O} /$ hexane.

${ }^{1} \mathrm{H}$ NMR $(400 \mathrm{MHz}) \mathrm{CDCl}_{3} \delta_{H}: 1.45(\mathrm{~d}, \mathrm{~J}=7 \mathrm{~Hz}, 3 \mathrm{H}$, $\left.\mathrm{C}^{-\mathrm{CH}_{3}}\right), 2.41\left(\mathrm{~s}, 3 \mathrm{H}, \mathrm{ArCH}_{3}\right), 4.5(\mathrm{~m}, 1 \mathrm{H}, \mathrm{H}-1), 4.8(\mathrm{~m}, 1 \mathrm{H}$, $\mathrm{NH}), \quad 5.99\left(\mathrm{~d}, \mathrm{~J}=3.2 \mathrm{~Hz}, 1 \mathrm{H}, \mathrm{H}-3^{\prime}\right), 6.17\left(\mathrm{~m}, 1 \mathrm{H}, \mathrm{H}-4^{\prime}\right), 7.2$ -7.7 (m. 5H, ArH, H-5')

(2R,6S)-6-hydroxy-2-methyl-1-tosyl-1,2-dihydropyridi n-3(6H)-one, 5: To a stirred solution of $100 \mathrm{mg}(0.376 \mathrm{mmol})$ of 4 in $2 \mathrm{~mL}$ of anhydrous $\mathrm{CH}_{2} \mathrm{Cl}_{2}, 0.16 \mathrm{~g}(0.66 \mathrm{mmol})$ of anhydrous m-CPBA $(70 \%)$ were gradually added. The reaction mixture was stirred at room temperature for 4 hours and then washed successively with $20 \% \mathrm{KI}(1 \mathrm{~mL}), 30 \% \mathrm{Na}_{2} \mathrm{SO}_{4}$ $(2 \mathrm{~mL})$, and $\mathrm{H}_{2} \mathrm{O}(2 \mathrm{~mL})$. The organic layer was extracted with brine, dried over $\mathrm{MgSO}_{4}$ and evaporated to dryness under vacuum. The resulting off-white residue was flash chromatographed with an eluting mixture of hexane/EtOAc $4: 1$ affording $0.09 \mathrm{~g}$ of 5 ( $85 \%$ yield), which recrystallizes from $\mathrm{Et}_{2} \mathrm{O} /$ hexane as off-white crystals.

${ }^{1} \mathrm{H}$ NMR $(400 \mathrm{MHz}) \mathrm{CDCl}_{3} \delta_{H}: 1.45(\mathrm{~d}, \mathrm{~J}=7 \mathrm{~Hz}, 3 \mathrm{H}$, C- $\left.\mathrm{CH}_{3}\right), 2.46\left(\mathrm{~s}, 3 \mathrm{H}, \mathrm{ArCH}_{3}\right), 4.5(\mathrm{~m}, 1 \mathrm{H}, \mathrm{H}-2), 4.9$ (br, $1 \mathrm{H}$, $\mathrm{OH}), \quad 6.1(\mathrm{~m}, 1 \mathrm{H}, \mathrm{H}-6), 6.24(\mathrm{~d}, \mathrm{~J}=10.2 \mathrm{~Hz}, 1 \mathrm{H}, \mathrm{H}-4), 7.09$ $(\mathrm{m}, \mathrm{J}=10.2,4.9 \mathrm{~Hz}, 1 \mathrm{H}, \mathrm{H}-5), 7.3-7.8(\mathrm{~m}, 4 \mathrm{H}, \mathrm{ArH})$.

\section{Conclusions}

The commercially available L-glucal substrate provided efficiently the molecule of dihydropyridin- $3(6 \mathrm{H})$-one in five steps and satisfactory overall yield (30.3\%). This compound can serve as crucial key intermediate for the efficient syntheses of various bioactive natural piperidine alkaloids.

\section{REFERENCES}

[1] Pinder, A.R., 1992, Azetidine, Pyrrole, Pyrrolidine, Piperidine, and Pyridine Alkaloids, Nat. Prod. Rep. 9, 491-504

[2] For more specific information on hydroxylated piperidines, see the following article and references within: Fleet, G.W.J., Fellows, L.E., Winchester, B., 1990, Plagiarisng Plants: Amino-sugars as a Class of Glycosidase Inhibitors. Bioactive Compounds from Plants, Ciba Foundation Symposium 154. Wiley: Chichester pp. 112-115

[3] (a) Jones, T.H., Blum, M.S., Robertson, H.G., 1990, Novel Dialkylpiperidines in the venom of the ant Monomorium-Delagoense, J. Nat. Prod. 53, 429-435. (b) Roth, H.J., Kleeman, A., 1988 Pharmaceutical Chemistry, John Wiley \& Sons; New York. (c) Numata, A., Ibuka, T., The Alkaloids, Brossi, A., 1987; Ed.; Academic Press: New York, Vol. 31, pp. 193-315

[4] de Raadt, A., Ekhart, C.W., Ebner, M., Stütz, A.E., 1997, In Glycoscience, Synthesis of Substrate Analogs and Mimetics, Driguez, H., Thieme, J. Eds, Springer Verlag: Berlin Heidelberg, , pp. 157-186

[5] (a) Bernacki, R.J., Korytnyk, W., 1985, Glycosidases in Cancer and Invasion Cancer Metastasis Rev. 4, 81-101. (b) Tsukamoto, K., Uno, A., Shimada, S., Imokaw, G., 1989, Nojirimycin Inhibits Pulmonary Metastasis of B16-F10 Murine Melanoma-Cells, Clin. Res. 37A, 722

[6] (a) Fleet, G.W.J., Karpas, A., Dwek R.A., Fellows, L.E., Tyms A.S., Petursson, S., Namgoong, S.K., Ramsden, N.G., Smith, P.W., Son, J.C., Wilson, F., Witty, D.R., Jacob, G.S., Rademacher, T.W., 1988, Inhibition of HIV replication by amino-sugar derivatives. FEBS Lett. 237, 128-132. (b) Gruters, R.A., Neefies, J.J., Tersmette, M., DeGroede, R.E., Tulp, A., Huiman, H.G., Miedema, F., Ploegh, H.L., 1987, Interference with HIV-induced syncytium formation and viral infectivity by inhibitors of trimming glucosidase, Nature, 330, 74-77

[7] Boucheron, C., Compain, P., Martin, O.R., 2006, A stereodivergent approach to 1-deoxynojirimycin, 1 - deoxygalactonojirimycin and 1-deoxymannojirimycin derivatives, Tetrahedron Lett. 47, 3081-3084

[8] Kennedy, A., Nelson, A., Perry, A. 2005, Exploitation in the two-directional synthesis of aza-C-linked disaccharide derivatives, Beilstein J. Org. Chem. 1:2

[9] Singh, O.V., Han, H., 2003, A general methodology for the asymmetric synthesis of 1-deoxyiminosugars, Tetrahedron Lett. 44, 2387-2391

[10] Tsukanov, S.V., Comins, D.L., 2011, Concise Total Synthesis of the Frog Alkaloid (-)-205 B., Angew. Chem. Int. Ed., 50, $8626-8628$

[11] Weintraub, P.M., Sabol, J.S., Kane, J.M., Borcherding, D.R., 2003 , Recent advances in the synthesis of piperidones and piperidines. Tetrahedron 59, 2953-2989

[12] a). Koulocheri, S.D., Pitsinos, E.N., Haroutounian, S.A., 2008, Stereoselective Syntheses of 2,6-disubstituted Piperidin-3-oles (alkaloid lipids). Current Organic Chemistry, 12, 1454-1467, b). Tzanetou, E.N., Kasiotis, K.M., Magiatis, P., Haroutounian, S.A., 2007, Synthesis of (R)- Dihydropyridones as Key Intermediates for an Efficient Access to Piperidine Alkaloids. Molecules, 12, 735-744 
[13] Appoh, F.E., Wheaton, S.L., Vogels, C.M., Baerlocher, F.J., Decken, A., Westcott, S.A., 2009, Synthesis, Structure, and Antifungal Activity of Dihydropyridones Containing Boronate Esters, Heteroatom Chemistry, 20, 56-63

[14] Elias, R.S., Saeed, B.A., Saour, K.Y., Al-Masoudi, N.A., 2008, Microwave assisted synthesis of dihydropyridones from curcumin. Tetrahedron Lett. 49, 3049-3051

[15] Donohoe, T.J., Connolly, M.J., Walton, L., 2009, Regioselective Nucleophilic Addition to Pyridinium Salts: A New Route to Substituted Dihydropyridones. Organic Letters, 11, $5562-5565$
[16] Feiqing, D., Ronny, W., Fei, W., Jimei, M., Li, J., Xue-Wei, L., 2011, A Short and Highly Efficient Synthesis of L-Ristosamine and L-epi-Daunosamine Glycosides. Organic Letters, 13, 652-655

[17] Hauser, F.M., Ellenberger, S.R., Ellenberger, W.P., 1988, A simple procedure for the preparation of L-hexoses, Tetrahedron Lett. 29, 4939-4942

[18] Thompson, A. S., Humphrey, G. R., De Marco, A. M., 1993, Mathre, D. J., Grabowski, E. J. J., Direct conversion of activated alcohols to azides using diphenyl phosphorazidate - A practical alternative to Mitsunobu conditions. J. Org. Chem. $58,5886-5888$ 